\title{
Lake Erie, phosphorus, and microcystin: Is it really the farmer's fault?
}

D.R. Smith, R.S. Wilson, K.W. King, M. Zwonitzer, J.M. McGrath, R.D. Harmel, R.L. Haney, and L.T. Johnson

\begin{abstract}
The size of the harmful algal blooms in western Lake Erie is strongly correlated with agricultural phosphorus (P) loading from tributaries. Despite farmers' efforts to reduce sediment-bound $\mathrm{P}$ loadings and fertilize using current guidance, the media and public have singled them out as the culprit in Lake Erie re-eutrophication. In this paper, two farmer surveys were used to evaluate if farmers in the Lake Erie region follow P fertilizer recommendations, and we also review historic and current $\mathrm{P}$ management guidance provided by the scientific community and agricultural industry. The majority (56\% to $80 \%$ ) of farmers apply $\mathrm{P}$ fertilizers at or below the current fertility recommendations. Wholesale agronomic changes (e.g., no-tillage adoption, crop cultivar advances, and fertilizer application and formulation) have occurred since current fertilizer recommendations were developed. Although crop P uptake mechanisms have not changed, these agronomic changes have altered $\mathrm{P}$ cycling in soil and water. Based on these results, it is time that the scientific community and agricultural industry acknowledge that our current guidance may be contributing to eutrophication. We must ask whether or not we have (1) developed appropriate fertility guidance, (2) developed and recommended appropriate practices to protect water quality, (3) adequately considered "the law of unintended consequences" in conservation recommendations, and (4) focused too much on short-term economic outcomes while disregarding environmental quality. Improved understanding, reconsideration of traditional recommendations, and wider farmer adoption of the most effective practices are needed to develop a sustainable agricultural system in the Western Lake Erie Basin that produces needed commodities while preserving ecosystem integrity.
\end{abstract}

Key words: eutrophication — fertilizer management—nutrient management - phosphoruswater quality

The "do not consume" order by the City of Toledo, Ohio, for drinking water in August of 2014 placed the spotlight on agricultural phosphorus ( $P$ ) loadings to Lake Erie (Fitzsimmons 2014; Wines 2014). The decision to prohibit human water consumption from the lake stemmed from detection of microcystin concentrations above $1.0 \mu \mathrm{g}$ $\mathrm{L}^{-1}$ in the treated drinking water, which is a drinking water standard set by the World Health Organization (WHO 2003). These elevated microcystin concentrations were the result of an intense harmful algal bloom of the cyanobacteria Microcystis centered over the Toledo drinking water intake. Phosphorus loading to the lake, especially in the spring (March through July), has been shown to significantly impact the extent of applying excess $\mathrm{P}$ to fields and not implementing management practices that decrease $\mathrm{P}$ losses. In many regions where P-related water quality issues arise, the primary culprit is manure applications; however, in the WLEB, manure applications represent less than $20 \%$ of $\mathrm{P}$ applications (King et al. 2017). It is undeniable that some farmers are not heeding the management recommendations of land grant universities, certified crop advisors (CCAs), Soil and Water Conservation Districts (SWCD), and USDA Natural Resources Conservation Service (NRCS) staff. However, some in the agricultural advisory community suggest that majority of farmers are following at least some, if not all, of the advice offered from these groups in regards to applying fertilizer at rates designed to optimize crop yields while protecting environmental quality. In this paper, we review current $\mathrm{P}$ fertility recommendations and results from two farmer surveys to determine the extent to which farmers in the Lake Erie region are following recommended $\mathrm{P}$ application rates. We also examine historical and current $\mathrm{P}$ management guidance by the scientific community and agricultural industry, and how it has impacted prevailing farming practices and $\mathrm{P}$ loss. While blame has been placed on the farming community for water quality issues such as the Toledo drinking water incident, we, as a scientific community and agricultural industry, must also acknowledge our role and accept some level of responsibility. We must ask ourselves if we have provided sufficient guidance to

Douglas R. Smith is a soil scientist with the USDA Agricultural Research Service (ARS) Grassland, Soil and Water Research Laboratory, Temple, Texas. Robyn S. Wilson is an associate professor of risk analysis and decision science in the School of Environment and Natural Resources at The Ohio State University, Columbus, Ohio. Kevin W. King is an agricultural engineer with the USDA ARS Soil Drainage Research Unit, Columbus, Ohio. Martha Zwonitzer is a North American field testing assistant with Monsanto in Lubbock, Texas. Josh M. McGrath is an Extension associate professor in the Department of Plant and Soil Sciences at the University of Kentucky, Lexington, Kentucky. R. Daren Harmel is the director of the USDA ARS Center for Agricultural Resources Research in Ft. Collins, Colorado. Rick L. Haney is a soil scientist with the USDA ARS Grassland, Soil and Water Research Laboratory, Temple, Texas. Laura T. Johnson is director of the National Center for Water Quality Research at Heidelberg University, Tiffin, Ohio. 
the farmer and consider whether or not we have (1) developed appropriate $\mathrm{P}$ fertility recommendations, (2) developed and recommended the appropriate practices to protect water quality, (3) adequately considered tradeoffs when providing conservation recommendations, and (4) focused too much on short-term economic outcomes without regard for environmental quality. The objectives of this paper are to evaluate the extent to which farmers adhere to current fertility guidance and set out priorities for research that will provide farmers with recommendations that optimize agronomic performance with water quality protection.

\section{Phosphorus Fertility Recommendations} Development of Recommendations. Historically, fertility recommendations have been based solely on the regulating services associated with soil fertility, while other ecosystem services, such as water contamination control, have been given little attention. Researchers developed P fertilizer recommendations to maximize yield as efficiently as possible relative to fertilizer cost (Thomas and Hanway 1968). In fact, during the 1960 s and 1970s, P fertilizer was relatively cheap compared to crop value (figure 1). Consequently, recommendations were designed to ensure there would be no chance of nutrient deficiency even in a high-yielding year (Nelson 1967). Due to the relationship between fertilizer price and crop value and the nonlinear relationship between fertilizer rate and yield (on responsive soils), the economic risk of under-fertilization was much greater than that of over-fertilization when viewed over multiple years. Furthermore, P was often described as "immobile" due to low soil solution P solubility. Thus, control of P loss from agricultural fields was synonymous with erosion control (Wadleigh and Dyal 1970; van Schilfgaarde et al. 1981). In one sense, the notion of $\mathrm{P}$ immobility was accurate since the amount that dissolves in solution is generally negligible relative to total P (Pierzynski 1991; Pierzynski et al. 2005); however, this is only true for soil P and not for $\mathrm{P}$ from either manure or fertilizer (Sommers and Sutton 1980; Young and Davis 1980; Smith and Moore 2005; Smith et al. 2005).

One could argue that simply changing soil test interpretation philosophy (e.g., from build and maintain to sufficiency approach) would require little effort or research.

\section{Figure 1} Crop and phosphorus fertilizer price indices (US\$) over time (USDA ERS 2016). Phosphate price index represents price paid by the producer in $1982=U S \$ 100$. Crop price index represents price received by farmers for all crops in 1990 to $1992=$ US\$100.

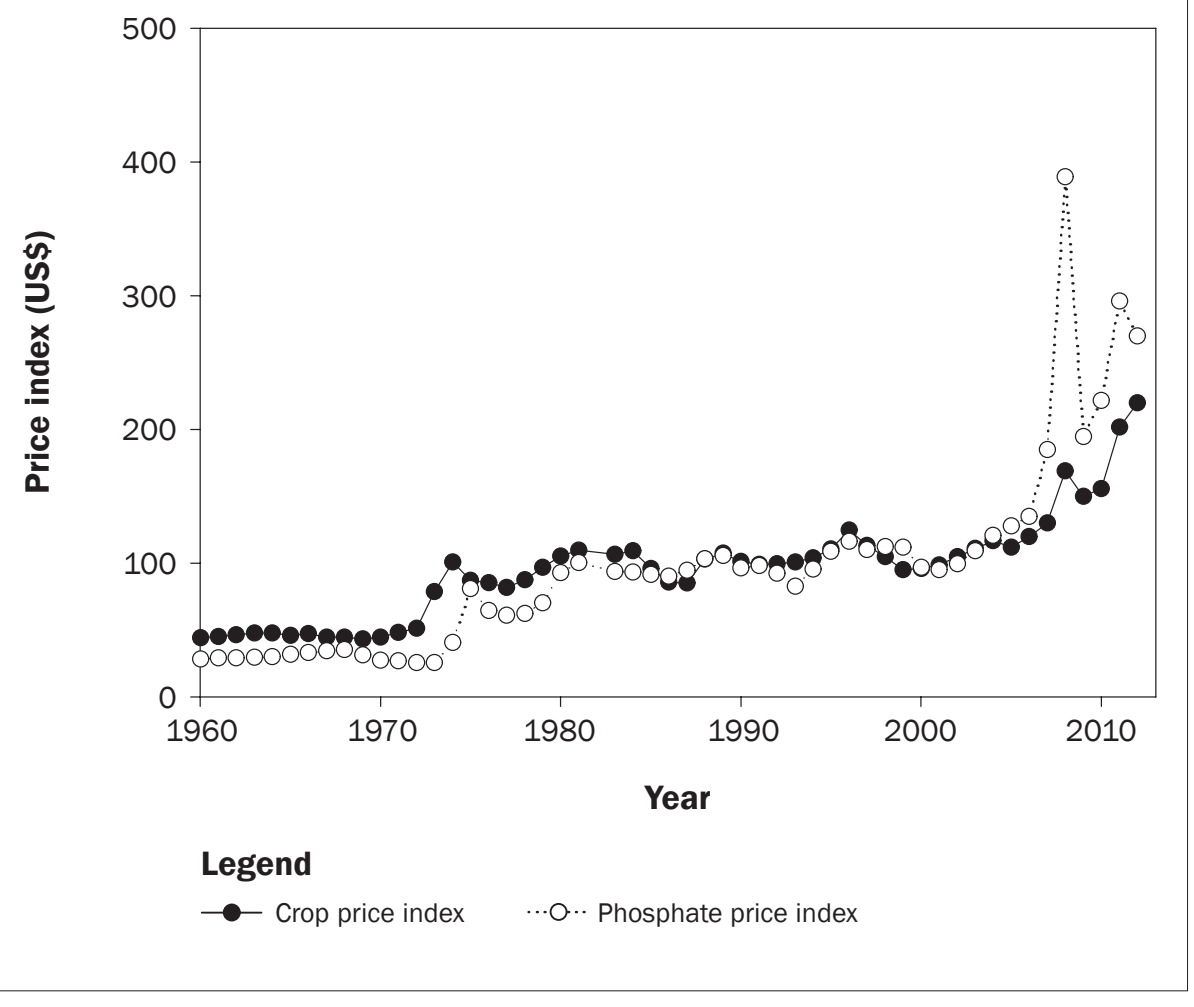

Further, we might contend that little has changed regarding fertilizer requirement, even as crop yields have changed. However, there are important knowledge gaps and shortcomings in our current use of soil testing. In many of the rainfed areas of the United States where acid soils are prominent, fertility recommendations were originally developed using the Bray soil test (Bray and Kurtz 1945). Since that time, many universities and private consultants have switched to fertilizer recommendations based on soil test $\mathrm{P}$ concentrations determined by Mehlich 3 extract (Mehlich 1984) or Mehlich 1 (Mehlich 1978). Very little, if any, soil test correlation and calibration work was done with the new extracts. Rather, in most cases a set of soils was analyzed using both the old and new methods, and a linear regression was developed to convert existing recommendations to the new soil test basis. Furthermore, some soil testing labs reported soil test $\mathrm{P}$ to farmers as Bray P, but the samples were actually analyzed using Mehlich 3 procedures and results were interpolated to a Bray $\mathrm{P}$ basis using correlations developed between the methods. Adding to the confusion, recommendations might be provided on a Bray
$\mathrm{P}$ basis (e.g., tri-state [Indiana, Ohio, and Michigan] fertilizer recommendations; tables 1 and 2) with the expectation that the end user will convert their soil test results to a Bray basis from Mehlich 3 as reported by the lab (Watson and Mullen 2007).

There is a pressing need to conduct correlation and calibration work with current soil test $\mathrm{P}$ methods to not only increase the confidence we have in current soil test critical levels, but also to increase the precision fertilizer recommendations. The need to increase the precision of fertilizer recommendations is ever more important with increasing adoption of variable fertilizer application based on subfield soil sampling. The shortcomings of current soil testing practices and associated fertilizer recommendations might be magnified when applied on a subfield basis through precision agriculture, particularly considering that critical soil test concentrations are likely both spatially and temporally variable at finer resolutions.

Research into high solubility P fertilizers began in the 1950s, and these studies were generally conducted on soils with low P status (Webb and Pesek 1958, 1959). In many instances over the last $30+$ years, farmers 
have been convinced by the communities that advise them that they cannot produce a crop without supplemental P. Therefore, some producers often apply additional $\mathrm{P}$ to $\mathrm{P}$ sufficient soils despite overwhelming evidence that economic return from increased yield is unlikely.

In the Lake Erie region over the past several years, there has been an intensifying call for an update to current fertility recommendations (i.e., the Tri-State Fertilizer Recommendations for Corn, Soybeans, Wheat, and Alfalfa [Tri-State Fertility Guide]) that reflects (1) multiple ecosystem services, including agronomic production and protection of water quality; (2) updated agronomic practices (e.g., no-tillage, lack of $\mathrm{P}$ fertilizer incorporation, and different P sources); (3) improvements in crop genetics and modern crop varieties; and (4) differences in soil properties such as organic matter content as well as regional differences in soils (and thus variables such as inherent $\mathrm{P}$ fixation). Table 1 provides the 1995 Tri-State Fertility Guide recommendations for corn (Zea mays L.). Although these recommendations were updated in 2012 to reflect current reasonable crop yields (table 2), the same equations governing the recommendations were maintained through simple extrapolation with greater yield goals. Thus, a more intensive and thorough evaluation of the $\mathrm{P}$ fertility requirements for modern cropping systems under various soil and crop conditions is a critical need.

Application Rates Relative to Recommendations. Two surveys were used to determine how closely farmers in the Lake Erie region adhere to fertility guidance. In the first survey, 26 Indiana farmers were personally interviewed regarding the cropping system attribute data for up to four fields, each from 2010 to 2012. Specific data collected included every activity that occurred on the field (i.e., tillage, planting, harvest, etc.), specific inputs (i.e., chemicals and fertilizers used, seeding rates and varieties used, etc.), crop yield, and specifics about the soils and fertility in each field. These cropping system attribute data were then used to determine if fertilizer applied to each field met or surpassed the fertility recommendation for the individual crop or crop rotation within the field. The $\mathrm{P}$ recommendation for each field and in each year was calculated based on the soil test P levels and crop yield. Where crop yield exceeded the $\mathrm{P}$ recommendations of

Table 1

Original phosphorus $(P)$ fertility recommendations for corn from the Tri-State Fertility Guide (Vitosh et al. 1995). Phosphorus recommendations are in units of $\mathrm{kg} \mathrm{Pha}^{-1}$. STP is the soil test P.

\begin{tabular}{llllll}
\hline \multirow{5}{*}{$\mathbf{S T P}\left(\mathbf{m g ~ k g}^{-\mathbf{1}}\right)$} & \multicolumn{5}{l}{ Yield goal $\left(\mathbf{M g ~ h a}^{-\mathbf{1}}\right)$} \\
\cline { 2 - 6 } & $\mathbf{6 . 3}$ & $\mathbf{7 . 5}$ & $\mathbf{8 . 8}$ & $\mathbf{1 0 . 1}$ & $\mathbf{1 1 . 3}$ \\
\hline 5 & 42 & 47 & 49 & 54 & 56 \\
10 & 29 & 34 & 37 & 42 & 44 \\
15 to 30 & 17 & 22 & 24 & 29 & 32 \\
35 & 10 & 10 & 12 & 15 & 17 \\
40 & 0 & 0 & 0 & 0 & 0
\end{tabular}

\section{Table 2}

Revised phosphorus $(P)$ fertility recommendations for corn from the revised Tri-State Fertility Guide (Agricultural Nutrients and Water Quality Working Group 2012). Phosphorus recommendations are in units of $\mathrm{kg} \mathrm{P} \mathrm{ha}^{-1}$. STP is the soil test $\mathrm{P}$.

\begin{tabular}{lccccccc}
\hline & \multicolumn{7}{l}{ Yield goal $\left(\mathbf{M g ~ h a}{ }^{-\mathbf{1}}\right)$} \\
\cline { 2 - 8 } STP $\left(\mathbf{m g ~ k g}^{-\mathbf{1}}\right)$ & $\mathbf{7 . 5}$ & $\mathbf{9 . 1}$ & $\mathbf{1 0 . 7}$ & $\mathbf{1 2 . 6}$ & $\mathbf{1 4 . 1}$ & $\mathbf{1 5 . 7}$ & $\mathbf{1 7 . 3}$ \\
\hline 5 & 47 & 51 & 56 & 61 & 66 & 71 & 76 \\
10 & 34 & 39 & 44 & 49 & 54 & 59 & 61 \\
15 to 30 & 22 & 27 & 32 & 37 & 42 & 47 & 49 \\
35 & 10 & 12 & 15 & 20 & 22 & 24 & 24 \\
40 & 0 & 0 & 0 & 0 & 0 & 0 & 0 \\
& & & & & & &
\end{tabular}

the traditional tri-state fertility recommendations (Vitosh et al. 1995), the updated fertility guidance was used (Agricultural Nutrients and Water Quality Working Group 2012). Since most farmers in the region only apply $\mathrm{P}$ fertilizer once during the crop rotation, the $\mathrm{P}$ recommendation was also calculated for the crop rotation (corn-soybean [Glycine $\max$ L.] or corn-soybean-wheat [Triticum aestivum L.]) in each field based on crop yield. The $\mathrm{P}$ applied to each field was then plotted against the $\mathrm{P}$ recommendation.

A second formal survey was conducted for farmers in Ohio. The sample population for this survey consisted of corn and soybean farmers within the Maumee River watershed (Burnett et al. 2015). Researchers from the colleges of Food, Agricultural, and Environmental Sciences and Arts and Sciences at The Ohio State University created three mail-back questionnaires used in this study. Each of the three survey versions included a section of questions about field management practices that were to be answered while the farmer considered a specific field with low, average, or high crop productivity. Of the approximately 12,000 addresses in the 24 counties of the Maumee Watershed, a random sample $(n=2,500$ for each version) of corn and soybean farmer addresses was purchased from a private sam- pling firm. The surveys were conducted following Dillman's tailored design method (Dillman 2000). In February of 2014, an announcement letter was sent to the random sample of farmers informing them that they would soon be receiving a survey in the mail. A cover letter and a survey booklet with prepaid return postage were sent to all participants a week later. Included with this first survey was a token incentive of a one dollar bill to increase response. In early March a reminder postcard was sent to participants who did not return the survey. In late March an additional mailing of the cover letters and survey booklets was sent out to those participants who had not yet responded. In late April, a final reminder letter was sent to participants.

The three surveys were mailed out to a total of 7,500 farmers $(n=2,500$ for each version). A total of 3,937 surveys were initially returned. In total, 2,232 surveys were used in this analysis. In this survey, field crop productivity was identified by crop yield history. Receivers of the questionnaire used for this study were asked about crop rotation, crop grown in 2012, crop grown in 2013, frequency of $\mathrm{P}$ fertilizer application, $\mathrm{P}$ fertilizer used, most recent soil test results, rate of P applied, and anticipated yield. As with the survey of Indiana farmers, the information from this survey was used to develop 
$\mathrm{P}$ recommendations. Actual $\mathrm{P}$ applied was then compared to the $\mathrm{P}$ recommendation of individual fields for a given year and for the crop rotation.

In the survey of Indiana farmers, out of 78 fields with three complete years of data (figure 2), 6 of the fields did not receive any $\mathrm{P}$ fertilizer from 2010 through 2012, and only 3 to $4 \mathrm{~kg} \mathrm{P} \mathrm{ha}{ }^{-1}$ was applied to 14 fields at the time of planting in years where corn was grown. When data were examined for only the corn year (beginning at harvest of the previous crop to allow for fall fertilizer applications), $49 \%$ of the fields had $\mathrm{P}$ application rates at or below the recommendations in the Tri-State Fertility Guide (figure 2a;) (Vitosh et al. 1995; Agricultural Nutrients and Water Quality Working Group 2012).

Many farmers will apply P fertilizers every other year, so the amount of $\mathrm{P}$ applied for the corn-soybean rotation was also compared to the $\mathrm{P}$ fertility recommendations from the Tri-State Fertility Guide (figure 2b). When P fertility for the rotation was considered, the $\mathrm{P}$ applications were closer to aligning with the recommendations, as $56 \%$ of the fields had $\mathrm{P}$ applied at or below the fertility recommendations, and an additional 17\% had $\mathrm{P}$ applied within $10 \mathrm{~kg} \mathrm{ha}^{-1}$ of the recommendation. Based on these analyses, $24 \%$ of the fields had more than $20 \mathrm{~kg} \mathrm{P} \mathrm{ha}^{-1}$ applied when the Tri-State Fertility Guide recommended no additional $\mathrm{P}$ fertilizer. Over-application of $\mathrm{P}$ relative to current fertility guidance could be a source of P losses to Lake Erie, although there are many other potential contributors than over-fertilizing roughly one-quarter of fields (Baker et al. 2017; Jarvie et al. 2017; King et al. 2015; Smith et al. 2007, 2015), so it is unlikely to be the only cause. Since the majority of fields have $\mathrm{P}$ applied near or below recommended levels, assigning blame for Lake Erie re-eutrophication to all farmers is unjustified, especially since those managing three-quarters of the fields are adhering to the current state-of-the-science fertility guidance.

In the survey of Ohio farmers in the Maumee River watershed (Burnett et al. 2015), $74 \%$ of fields met or were below the one year tri-state fertility recommendations (figure 3a). When $\mathrm{P}$ recommendations for the crop rotation were evaluated, $90 \%$ of the fields were determined to meet or be fertilized at or below the recommendations (figure 3b). This includes 1,301 fields (58\%) that received no $\mathrm{P}$ application for the 2013

\section{Figure 2}

Phosphorus ( $\mathrm{P}$ ) applied by fertilizer type graphed against the $\mathrm{P}$ recommended from the Tri-State Fertility Guide for (a) the corn crop in the rotation and (b) the entire rotation (corn-soybean or corn-soybean-wheat). These data represent 78 fields and were collected during interviews with 26 farmers in Indiana. Note that not all fields represented in this data set are from the Western Lake Erie Basin.

(a)

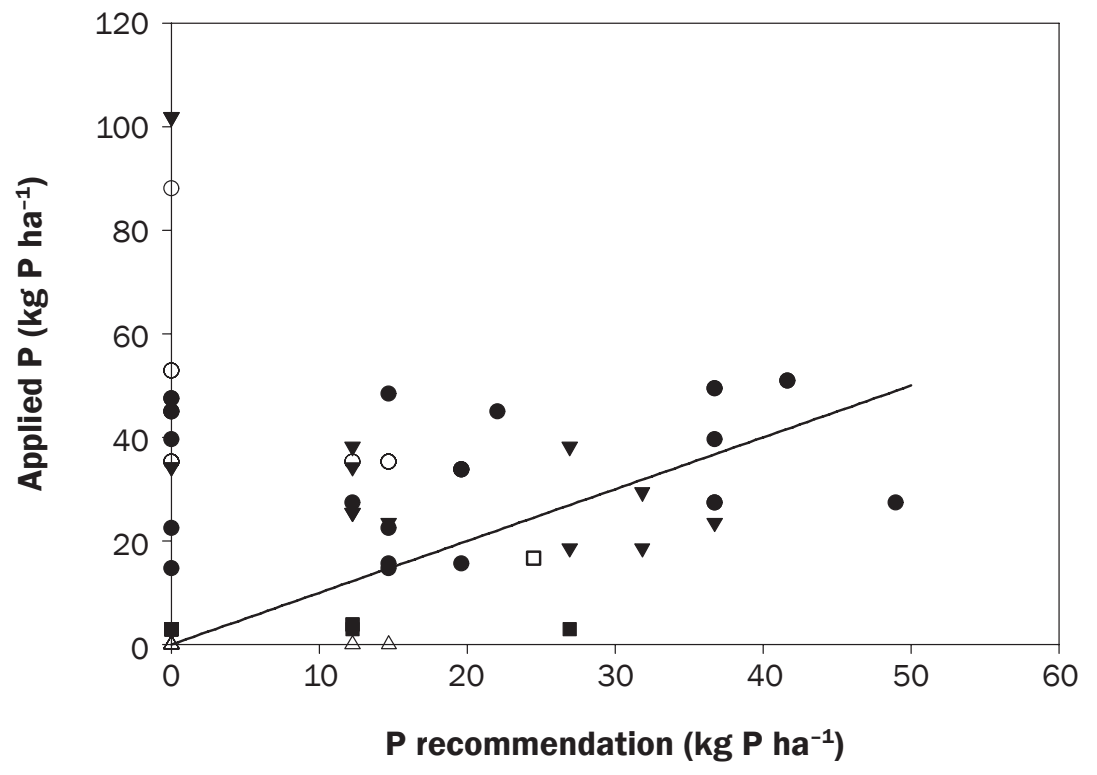

(b)

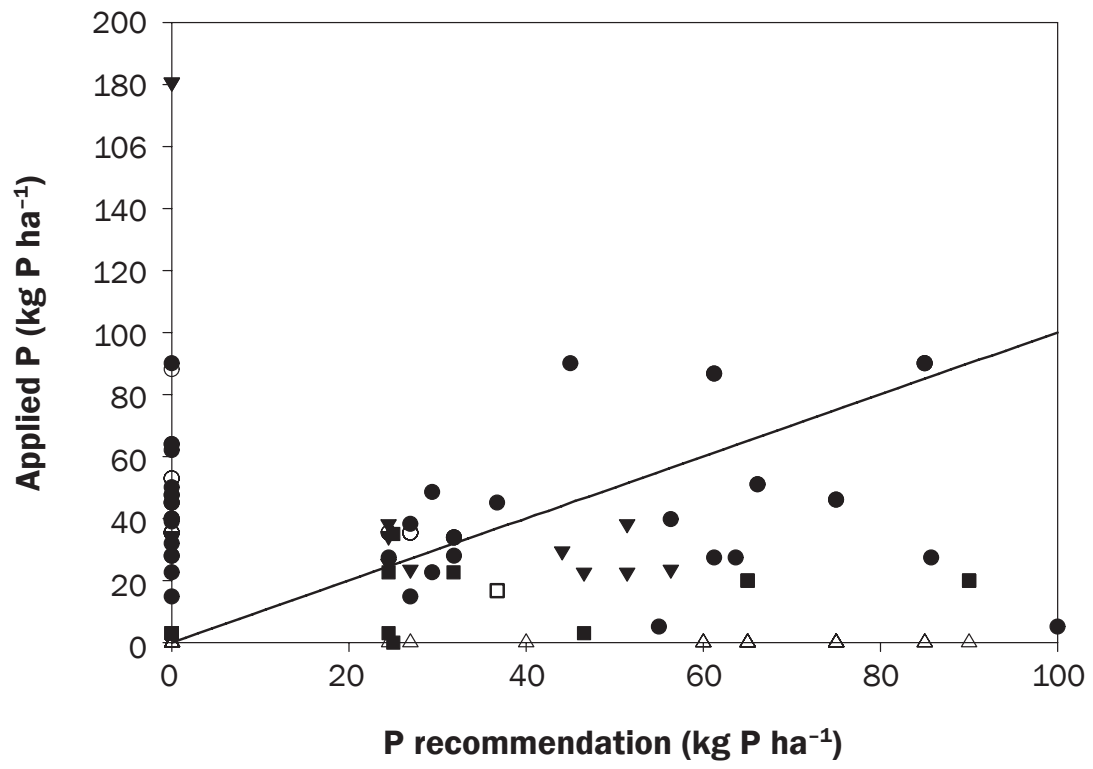

Legend
- Diammonium phosphate O Poultry litter
$\checkmark$ Monammonium phospate
$\triangle$ None 
crop. Of those, 670 fields (30\%) had both a zero recommended rate and zero $\mathrm{P}$ applied. Only 102 fields $(<5 \%)$ had a $\mathrm{P}$ application when there was a zero $\mathrm{P}$ recommendation. Phosphorus recommendations were exceeded in 216 fields. If we assume that $\mathrm{P}$ applications are made every other year, and we double the number of fields that exceed $\mathrm{P}$ recommendations for the crop rotation, then roughly $19 \%$ of the fields will exceed $\mathrm{P}$ recommendations for the crop rotation.

These surveys correspond well to studies examining the ranges in soil test levels across the WLEB. In a study of soil test P (as Mehlich 3) in the Sandusky River Basin, as well as from a database of Ohio soil tests for the WLEB, most soils (70\%) were within the "build-up" or "maintenance" ranges for corn and soybean (Baker et al. 2017). This implies that only $30 \%$ of fields were bad actors, and further analysis suggests that only targeting reductions in this 30\% would be insufficient to reach reductions required to reduce algal blooms in Lake Erie. As Baker et al. (2017) concluded, "Achieving a 40\% reduction in dissolved reactive $\mathrm{P}$ loading will require adoption of BMPs in fields across the full range of agronomic soil-test levels."

Many farmers in the survey of Ohio farmers report using fertilizer rates well below the $\mathrm{P}$ recommendations. From this survey, there were 1,454 fields that apply fertilizer to fields where $\mathrm{P}$ is recommended. Of these fields, $40 \%$ have fertilizer applied at rates that do not exceed $80 \%$ of the fertility recommendations. This suggests that a substantial number of fields are receiving less $\mathrm{P}$ than recommended. Further investigation into these farms is warranted to determine how their management affects $\mathrm{P}$ sustainability, as well as to understand what drives the nutrient management decisions of these farmers.

Comparing those producers applying $\mathrm{P}$ fertilizers at or below versus above recommended rates, we see that the individuals applying above recommended rates are older, with more years farming, and are more likely to be retired from another occupation ( $t$-test $p<0.05)$. They also have stronger "productionist" identities, indicating that they are more likely to believe that a "good farmer" is one who has the highest yields per hectare, has the highest profits per hectare, uses the latest technology, etc. They are also less concerned about the seriousness of nutrient loss and associated algal bloom issues. These results indicate that the individuals not fol-

\section{Figure 3}

Phosphorus $(P)$ applied to 2,232 Ohio fields in 2013 as a function of $P$ recommended based on soil test $P$ and yield goals for (a) the year in which the fertilizer application was made, and (b) the crop rotation grown (corn-soybean or corn-soybean-wheat) in the field.

(a)

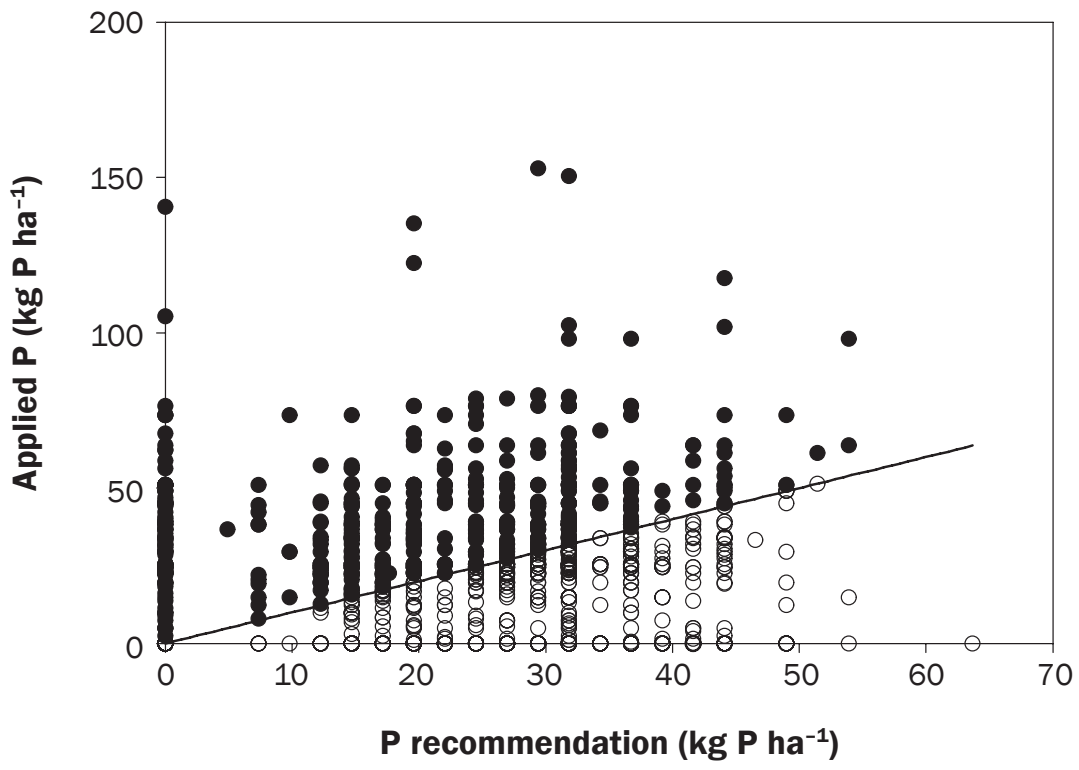

(b)

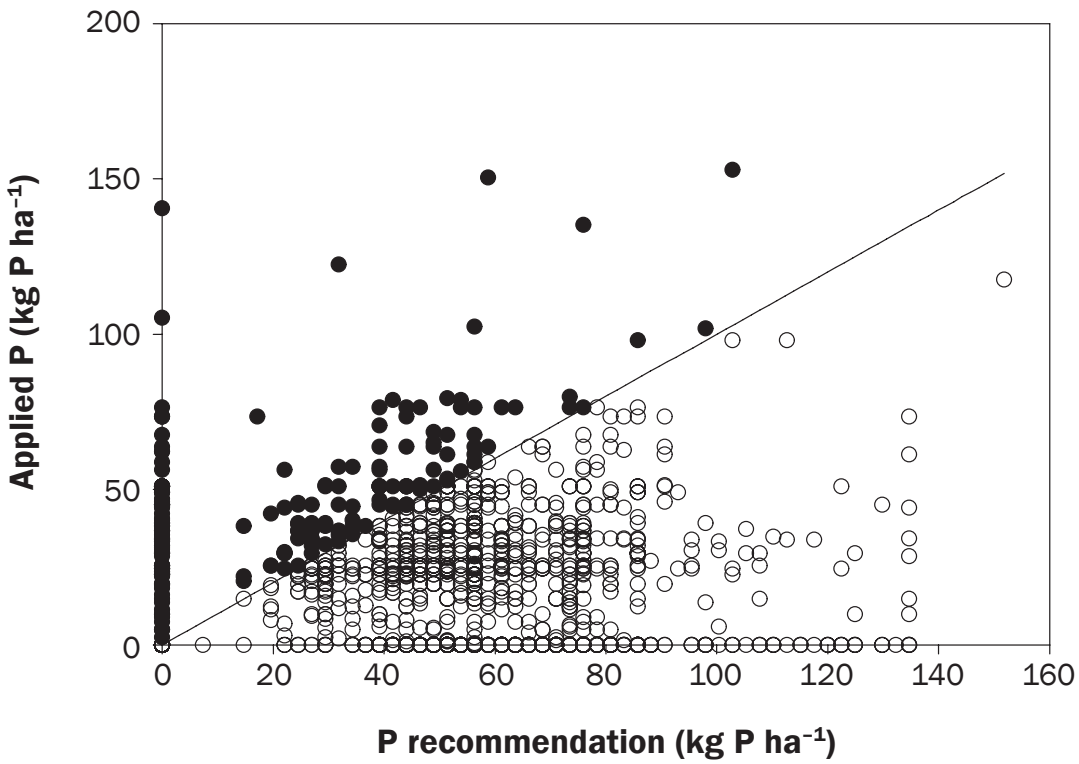

\section{Legend}

- Exceeds recommendation

O Does not exceed recommendation

- $1: 1$ line

lowing recommended rates are perhaps a bit more established, which may make them more likely to maintain agronomic production using older or status quo management guidelines. Anecdotally, from the smaller study of Indiana farmers, one 80-year-old farmer mentioned that he was once told to apply $449 \mathrm{~kg} \mathrm{P} \mathrm{ha}{ }^{-1}$, and it seemed to work so he would continue to use that practice. From a motivational standpoint, these individuals may think that applying higher $\mathrm{P}$ rates than recommended maximizes productivity while not having enough $\mathrm{P}$ results in negative economic consequences through potentially decreased yield. In addition to it being challenging to convince these indi- 
viduals to change given their core identity and beliefs, it is not likely that changing the behavior of this minority will solve the issues in western Lake Erie. We currently have no evidence that these individuals are farming a particularly large proportion of the land. Given the age of this potentially resistant minority, it is likely that as these individuals age and retire from farming, they will be replaced with individuals who are more similar in their beliefs and characteristics to the current majority who are concerned about nutrient loss and more likely to adopt current recommendations. In the meantime, working with the $\sim 80 \%$ of producers who are applying rates near appropriate rates to further optimize those rates or to increase adoption of subsurface placement and other recommended practices may be the best way to achieve the goal of decreased agricultural $\mathrm{P}$ contributions to the lake.

The survey of Ohio farmers reports a higher number of farmers adhering to current fertility guidance. It should be noted that in the larger data set, the farmers were asked about the yield goal they use for fertilizer applications. The survey of Indiana farmers did not ask about yield goal, but farmers did provide information on the actual yields harvested in their fields. The lower relative number of farmers achieving a level of $\mathrm{P}$ sustainability as a function of their fertilizer applications in the small study may be due to actual yields being lower than the yield goals. Farmers apply fertilizers before the growing season, so it is not reasonable for them to know the actual yield they will harvest while planning operations for a crop.

\section{Prevailing Practices that Affect Phosphorus Fertilization}

Rental Agreements. Approximately 51\% of the farmland in Ohio and roughly $54 \%$ in Indiana is rented or leased (USDA NASS 2012; Reimer et al. 2012). Most of these rental agreements require the tenant to maintain the fertility of the field. Thus, even if the field has excessive soil test P levels, the farmer is contractually bound to apply P fertilizer equal to the crop removal rate. Many farmers in the Lake Erie region are aware of the risks to water quality by applying $\mathrm{P}$ where it is not needed (Burnett et al. 2015) and will not apply $\mathrm{P}$ fertilizer on fields that they own, but they do apply $\mathrm{P}$ fertilizer to rented fields due to contractual obligations. Manure applications also represent a distinct minority of the nutrient sources applied within the WLEB (less than 20\% of the P applied [USDA NRCS 2016]). Absentee landowners who require their tenants to maintain fertility level in fields, even when those levels are excessive, therefore share responsibility for the water quality problems in Lake Erie.

Phosphorus Sources. The dominant sources of fertilizer $\mathrm{P}$ in the WLEB are monoammonium phosphate (MAP) and diammonium phosphate (DAP). From the farmers interviewed in the smaller survey, $57 \%$ of the fields that had any $\mathrm{P}$ fertilizer applied (organic or inorganic) used MAP or DAP. In the larger survey, $85 \%$ of $\mathrm{P}$ applied in 2013 were fertilized with MAP or DAP. These sources along with ammonium poly-phosphate (Poly) and triple superphosphate (TSP) contain more than $90 \%$ of their total $\mathrm{P}$ in the soluble form (table 3 ).

Many farmers assume that the majority of the $\mathrm{P}$ applied to their fields will be taken up by the crop. However, most studies indicate that less than $10 \%$ of fertilizer $\mathrm{P}$ will be taken up by the crop to which it is applied, although $\mathrm{P}$ use efficiency as high as 30\% has been reported (Withers et al. 2005). Thus, when highly soluble $\mathrm{P}$ sources are applied, more than $70 \%$ will be either sorbed by the soil or be lost to the environment. For example, Smith et al. (2016) found as much as $19 \%$ of applied fertilizer P can be lost to the environment through surface runoff during a single event (Smith et al. 2016). Phosphorus losses from plots and fields have shown that surface runoff $\mathrm{P}$ loss can account for $0.7 \%$ to $42 \%$ of the $\mathrm{P}$ applied as fertilizer (Hart et al. 2004). Thus, in regions like the WLEB where dissolved reactive $\mathrm{P}(\mathrm{DRP})$ is a primary concern, fertilizing with the most soluble forms of P may be ill-advised. As such, the scientific community and agricultural industry need to better educate farmers about the increased risk of $\mathrm{P}$ loss when applying highly soluble fertilizer to their fields and perhaps recommend alternative $\mathrm{P}$ sources that are less soluble.

Fertilizer Application Timing and Method. The majority of $\mathrm{P}$ fertilizers are applied between harvest of one crop and establishment of the following crop. In the typical WLEB corn-soybean rotation, the "fertilizer spreading season" is usually October through April. Regulations have further decreased the time farmers can spread manure on their fields. For example, Indiana has banned manure applications to frozen or snow covered ground (Indiana Register 2012). Ohio also limits fertilizer and manure applications during the winter as well as before precipitation events (Senate Bill 1) and requires anyone who spreads fertilizer on more than 20 ha to obtain a certified fertilizer applicators license (Senate Bill 150; Ohio Legislature 2015). While this may be effective at reducing the excess loss of recently applied $\mathrm{P}$, it further constrains fertilizer application timing (Williams et al. 2011, 2012).

The application of $\mathrm{P}$ during the nongrowing season coincides with the period of greatest P losses from fertilizer applications (King et al. 2015, 2016). Studies have shown that $\mathrm{P}$ losses are generally much greater immediately after application than in the weeks to months after application (Smith et al. 2007; Harmel et al. 2009). Further, since potential evapotranspiration is generally lowest during this period (King et al. 2014), an equal volume precipitation event will result in greater $\mathrm{P}$ losses during the "fertilizer spreading season" compared to the growing season. The November 1 to April 15 fertilizer spreading season encompasses approximately $45 \%$ of the year, during a period with minimal water and nutrient uptake by plants. For hydrologic years 2008 to 2011, an average of $68 \%$ and $67 \%$ of the annual DRP and TP loads, respectively, for the Maumee River were delivered to Lake Erie during the fertilizer spreading season (figure 4).

Broadcasting is the most common method for farmers to apply $\mathrm{P}$ fertilizers as large fields can be covered quickly. Large investments have also been made recently by fertilizer dealers to purchase fertilizer spreading equipment that allows for varying the rate of dry product application as it moves through the field (i.e., variable rate technology). Incorporation of fertilizer through tillage after application, injection, or placed $5 \mathrm{~cm}$ below and $5 \mathrm{~cm}$ to the side of the seed row may be the best methods to minimize P losses, particularly soluble P via runoff (Daverede et al. 2004; McConnell et al. 2013; Smith et al. 2016). In fields where higher rates of $P$ fertilizer are needed (i.e., based on tables 1 and 2), the cost associated with injecting fertilizers into the soil may be prohibitively high. Yet, there is some evidence that where surface levels of $\mathrm{P}$ are high $\left(20 \mathrm{mg} \mathrm{kg}^{-1}\right.$ or $20 \mathrm{ppm}$ higher than the agronomic level), a one-time inversion tillage via moldboard plow would 
reduce the risk of DRP runoff by about 30\% (Baker et al. 2017).

It is difficult, however, for farmers to apply at times other than the "fertilizer spreading season" given logistical and infrastructure constraints within our current agronomic system. These constraints include current regulations, crop rotation, fertilizer availability, and recommended $\mathrm{P}$ rates necessary for current production levels. Farmers may therefore be constrained to apply $\mathrm{P}$ during this period largely by factors that are out of their immediate control.

\section{Conservation Guidance and Tradeoffs}

Conservationists spent much of the last half of the twentieth century developing and implementing practices to decrease soil erosion. It was understood that $\mathrm{P}$ losses were primarily associated with sediments; thus, erosion control practices limited $\mathrm{P}$ loss. However, this is not necessarily true for DRP. The problem occurred, not due to ignorance of the small amounts of dissolved losses (Logan and Adams 1980), but because of the disconnection between aquatic ecology and the inherent difference in the scale of DRP impact on crops compared to aquatic ecosystems. For example, the critical P concentration in solution necessary for growing various crops ranges from 0.008 to $1.6 \mathrm{mg}$ $\mathrm{L}^{-1}$ (Hue and Fox 2010). However, depending on $\mathrm{N}$ concentration and Microcystis strain, dissolved $\mathrm{P}$ concentrations as low as $0.11 \mathrm{mg}$ $\mathrm{L}^{-1}$ can cause a dramatic increase in Microcystis growth (Vezie et al. 2002).

We cannot discount the tremendous efforts that have reduced erosion in vast swaths of agricultural landscapes, as practices such as no-tillage and grassed waterways are effective in erosion control. These practices do appear to improve water quality associated with sediment and TP reductions (Richards et al. 2009). However, there is a growing body of evidence that practices that keep the ground covered can result in divergent DRP and TP losses (Smith et al. 2015) because of the indirect effects of adapting fertilizer application techniques to accompany erosion control practices. Indeed, Williams et al. (2016) found that surface broadcast fertilizer on a no-till field significantly increased $\mathrm{P}$ concentrations in tile discharge compared to fertilizer that was incorporated into the soil. In addition, Baker et al. (2017) found substantial stratification of $\mathrm{P}$ in soils, even though many were in rotational no-till and

Table 3

Fertilizer formulation, phosphorus $(P)$ content, and solubility.

\begin{tabular}{lllll}
\hline Source & $\begin{array}{l}\text { Formulation } \\
\left(\mathbf{N}-\mathbf{P}_{\mathbf{2}} \mathbf{O}_{\mathbf{5}}-\mathbf{K}_{\mathbf{2}} \mathbf{0}\right)\end{array}$ & $\begin{array}{l}\text { Total } \mathbf{P} \\
\left(\mathbf{g ~ k g}^{-\mathbf{1}}\right)\end{array}$ & $\begin{array}{l}\text { Soluble } \mathbf{P} \\
\left(\mathbf{g ~ k g}^{-\mathbf{1}}\right.\end{array}$ & $\begin{array}{l}\text { Solubility } \\
\mathbf{( \% )}\end{array}$ \\
\hline Monoammonium phosphate & $11-52-0$ & 227 & 212 & 93.4 \\
Diammonium phosphate & $18-46-0$ & 201 & 185 & 92.1 \\
Ammonium polyphosphate & $11-37-0$ & 166 & 165 & 99.3 \\
Triple superphosphate & $0-46-0$ & 201 & 200 & 99.5 \\
Single superphosphate & $0-18-0$ & 78.5 & 59.9 & 76.2 \\
Bone meal & $2-14-0$ & 61.1 & 5.9 & 9.6 \\
Rock phosphate & $0-3-0$ & 13.1 & 0.1 & 0.9 \\
\hline Notes: $\mathrm{N}=$ nitrogen. $\mathrm{P}_{2} \mathrm{O}_{5}=$ phosphorus pentoxide. $\mathrm{K}_{2} \mathrm{O}=$ potassium oxide. &
\end{tabular}

received chisel or disk plowing prior to corn $(72 \%)$. Conservationists and scientists failed to recognize that surface crop residues can be a significant DRP runoff source (Sharpley 1981; Sharpley et al. 1992). Instead, they supported the notion that $\mathrm{P}$ must be surface applied to maintain no-till conditions. In an era when incorporation of fertilizers was being discouraged, highly soluble P fertilizers were desirable because they encouraged fertilizer $\mathrm{P}$ to leach into the root zone. However, coupling surface application and highly soluble fertilizers has significantly exacerbated DRP loss in both surface runoff and tile drainage (Jarvie et al. 2017).

Managing for multiple resource concerns can be difficult due to competing performance objectives. Sediment enrichment of surface waters contributes not only to total $\mathrm{P}$ loading, but also other contaminants and degrades water quality in its own right. However, if controlling sediment loads was all that was required to reduce P-related eutrophication in Lake Erie this would have not become an issue, given decreases in discharge-normalized sediment loading seen since the 1980s (Richards et al. 2009). Nonetheless, since roughly 2002 the severity and extent of algal blooms have increased, and this increase is predominately correlated with spring DRP loading, mostly via stormpulsed runoff (Stumpf et al. 2012, 2016).Thus, conservation practices that reduce stormflow discharge, especially during critical periods such as the spring, are likely needed to minimize the impact of intensive agriculture on Lake Erie. Further, practices designed to reduce nitrate $\left(\mathrm{NO}_{3}\right)$ loading will not necessarily solve DRP related resource concerns. For example, cover crops provide a safety net to partially recover $\mathrm{N}$ applied in excess of crop uptake during a growing season. However, research has shown that they can be a source of DRP to runoff in regions where they can freeze and thaw during the winter (Bechmann et al. 2005). In effect, conservation practices are spatially and temporally variable in the effectiveness and they must be carefully matched to performance objectives. In some cases all resource objectives cannot be met, and an open dialogue is necessary to choose between the lesser of two "evils," as the tradeoffs between agronomic production and environmental outcomes may sometimes be mutually exclusive (Kleinman et al. 2015).

One cannot assume that more judicious use of fertilizers will be sufficient to solve Lake Erie eutrophication, as it will likely take many conservation practices to avoid, control, and trap nutrients as they flow through the system. Applying multiple conservation practices on a single field does seem to be an effective method of addressing multiple resource concerns (Francesconi et al. 2015; Her et al. 2016). Thus, holistic recommendations to farmers to adopt several practices on a field are likely needed to address multiple resource concerns. We also cannot make recommendations to solve the DRP issue from agricultural fields without recognizing that our solutions may result in exposing other resource concerns. While we are addressing DRP losses, we must therefore be aware of how our recommendations may affect other aspects of the farming system as a whole. Farmers following the best available guidance on conservation practices should not be denigrated for increased DRP loading leading to eutrophication within Lake Erie, as most of them were (and maybe still are) unlikely aware of the tradeoffs and nuances related to conservation practice adoption. Instead, we as the community that develops conservation guidance need to be forthright about the benefits and shortcomings of our recommendations and quickly develop guidance and conservation practices that will 


\section{Figure 4}

(a) Soluble phosphorus (P) and (b) total P loads from the Maumee River during the 2008 to 2011 hydrologic years (HY; starting October 1 ). The vertical lines roughly represent crop harvest (November 1) and the target date to start planting corn (April 15), between which is the period when commercial fertilizers are generally spread. The values on the right side of the graph indicate how much of the annual load occurred during the "fertilizer spreading season."

(a)

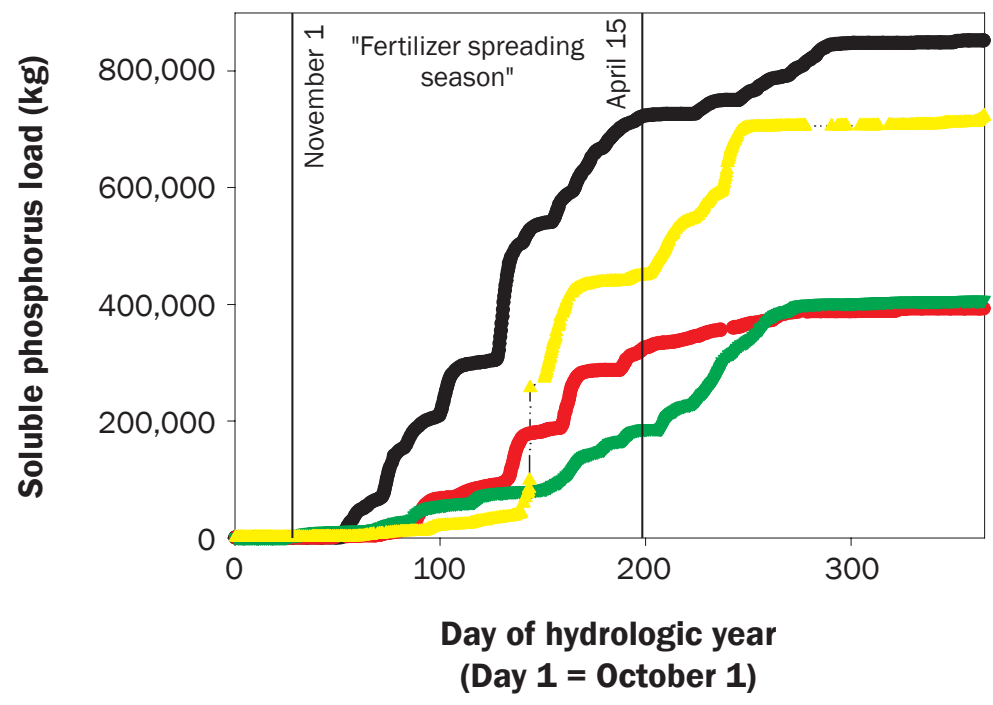

Legend

- HY08 soluble P $\mathrm{P}$ HY10 soluble P

- HY09 soluble P $\quad$ HY11 soluble P

(b)

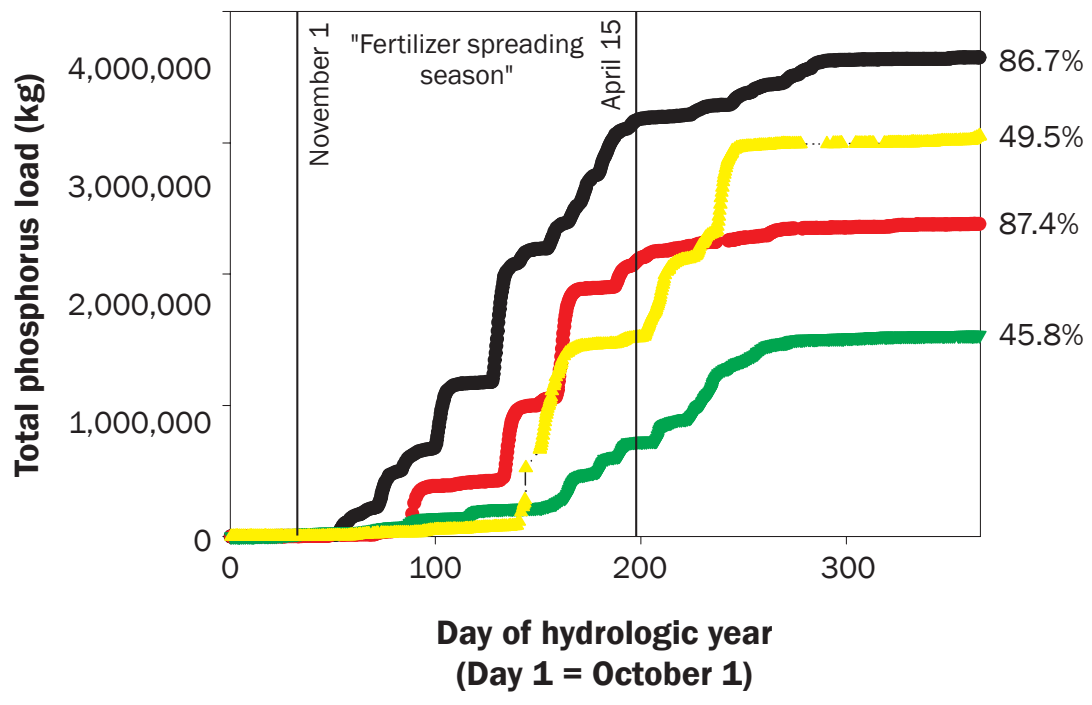

Legend

- HY08 total P $\quad$ P HY10 total P

- HY09 total P $\quad$ HY11 total P
$84.6 \%$

$61.9 \%$

$44.3 \%$

$81.1 \%$ economics), and potential unintended consequences within the watershed. To avoid further unintended consequences, an interdisciplinary approach is necessary to better understand the complex agro-ecosystem and the impact of nutrient management.

Environmental degradation has occurred despite the majority of farmers adhering to current fertility recommendations. It is also likely that those not adhering to recommendations are not the sole cause of the problem, and may also be less likely to adapt their practices moving forward. Thus, the recommendations, as well as the prevailing practices that affect $\mathrm{P}$ fertility management, must be carefully assessed. The farmer who follows these recommendations and survives inside the constructs of the fertility infrastructure is no more culpable in contributing to the DRP loading than those providing him/her with advice and tools to manage nutrients on the farm. It is likely that this farmer is the one who will further adjust their practices in response to thoughtful recommendations made by trusted advisors. Thus, we present a clarion call to consider not only agronomic provisioning and economics in fertility recommendation, but also the potential for environmental degradation, and to provide more holistic and tailored recommendations to the farming population who is largely ready and willing to adjust their practices (Wilson et al. 2014).

Moving forward, we recommend researchers consider the following to guide the development of fertility recommendations into the future:

- There is a pressing need to calibrate soil test methods to yield response to improve precision fertilizer recommendations.

- Intensive evaluation of $\mathrm{P}$ fertility requirements for modern cropping systems (i.e., new high yielding hybrids and no-till management).

- Encourage the use of yield history as a basis for yield goal. 
- Present farmers with risk management information (i.e., the risk to yield of not fertilizing or the risk of contributing to $\mathrm{P}$ loss when using a particular fertilizer source at a specific application timing).

- Develop a better understanding of P fertilizers' solubility related to plant uptake and runoff loss risk.

- Evaluate alternative P application timings/methods that will limit risk to loss while not sacrificing yield potential.

- Recognize competing performance objectives and tradeoffs of adopting new practices, and anticipate the law of unintended consequences of our recommendations.

\section{Disclaimer}

The United States Department of Agriculture (USDA) is an equal opportunity provider and employer. Mention of a company or trade name is for description only and does not imply endorsement by the USDA.

\section{References}

Agricultural Nutrients and Water Quality Working Group. 2012. Directors' agricultural nutrients and water quality working group: Final report and recommendations. Ohio Department of Natural Resources, Ohio Department of Agriculture, Ohio Environmental Protection Agency. http://www.agri.ohio.gov/topnews/waterquality/ docs/FINAL_REPORT_03-09-12.pdf.

Baker, D.B., L.T. Johnson, R.B. Confessor, and J.P. Crumrine. 2017. Vertical stratification of soil phosphorus as a concern for dissolved phosphorus runoff in the Lake Erie Basin. Journal of Environmental Quality doi:10.2134/jeq2016.09.0337.

Bechmann, M.W., P.J. Kleinman, A.N. Sharpley, and L.S. Saporito. 2005. Freeze-thaw effects on phosphorus loss in runoff from manure and catch-cropped soils. Journal of Environmental Quality 34(6):2301-2309.

Bray, R.H., and L.T. Kurtz. 1945. Determination of total, organic, and available forms of phosphorus in soils. Soil Science 59(1):39-46.

Burnett, E.A., R.S. Wilson, B. Roe, G. Howard, E. Irwin, W. Zhang, and J. Martin. 2015. Farmers, phosphorus and water quality: Part II-A descriptive report of beliefs, attitudes and best management practices in the Maumee Watershed of the Western Lake Erie Basin. Columbus, OH: The Ohio State University, School of Environment and Natural Resources.

Chaffin, J.D., T.B. Bridgeman, S.A. Heckathorn, and S. Mishra. 2011. Assessment of Microcystis growth rate potential and nutrient status across a trophic gradient in western Lake Erie. Journal of Great Lakes Research 37:92-100.

Daverede, I.C., A.N. Kravchenko, R.G. Hoeft, E.D. Nafziger, D.G. Bullock, J.J. Warren, and L.C. Gonzini. 2004.
Phosphorus runoff from incorporated and surfaceapplied liquid swine manure and phosphorus fertilizer. Journal of Environmental Quality 33(4):1535-1544.

Dillman, D.A. 2000. Mail and Internet Surveys:The Tailored Design Method, 2nd edition. New York: Wiley.

Fitzsimmons, E.G. 2014. Tap water ban for Toledo residents. The New York Times. August 3, 2014. http://www. nytimes.com/2014/08/04/us/toledo-faces-secondday-of-water-ban.html?_r=0.

Francesconi, W., D.R. Smith, D.C. Flanagan, C. Huang, and X. Wang. 2015. Modeling conservation practices in APEX: From the field to the watershed. Journal of Great Lakes Research 41(3):760-769.

Harmel, R.D., D.R. Smith, R.L. Haney, and M. Dozer. 2009. Nitrogen and phosphorus runoff from cropland and pasture fields fertilized with poultry litter. Journal of Soil and Water Conservation 64(6):400-412, doi:10.2489/jswc.64.6.400.

Hart, M.R., B.F. Quin, and M.L. Nguyen. 2004. Phosphorus runoff from agricultural land and direct fertilizer effects: A review. Journal of Environmental Quality 33(6):1954-1972.

Her, Y., I. Chaubey, J. Frankenberger, and D. Smith. 2016. Effect of conservation practices implemented by USDA programs at field and watershed scales. Journal of Soil Water Conservation 71(3):249-266, doi:10.2489/ jswc.71.3.249.

Hue, N.V., and R.L. Fox. 2010. Predicting plant phosphorus requirements for Hawaii soils using a combination of phosphorus sorption isotherms and chemical extraction methods. Communications in Soil Science and Plant Analysis 41:133-143.

Indiana Register. 2012. Title 327 Water Pollution Control Board: Final Rule LSA Document \#09-615(F). http://www.in.gov/legislative/iac/20120307-IR327090615FRA.xml.pdf.

Jarvie, H.P., L.T. Johnson, A.N. Sharpley, D.R. Smith, D.B. Baker, T. Bruulsema, and R. Confessor. 2017. Increased soluble phosphorus loads to Lake Erie: Unintended consequences of conservation practices? Journal of Environmental Quality 46(1):123-132.

King, K.W., N.R. Fausey, and M.R. Williams. 2014. Effect of subsurface drainage on streamflow in an agricultural headwater watershed. Journal of Hydrology 519:438-445.

King, K.W., M.R. Williams, and N.R. Fausey. 2015. Contributions of systematic tile drainage to watershedscale phosphorus transport. Journal of Environmental Quality 44(2):486-494.

King, K.W., M.R. Williams, and N.R. Fausey. 2016. Effect of crop type and season on nutrient leaching to tile drainage under a corn-soybean rotation. Journal of Soil and Water Conservation 71(1):56-68, doi:10.2489/ jswc.71.1.56.

King, K.W., M.R. Williams, D.R. Smith, G.A. LaBarge, J.M. Reutter,E.W.Duncan, L.A. Pease, and N.R. Fausey. 2017. Directionally correct practices to address agricultural phosphorus loss in artificially drained landscapes. Journal of Soil and Water Conservation 73(1):38-50.

Kleinman, P.J.A., A.N. Sharpley, P.J.A. Withers, L. Berström, L.T. Johnson, and D.G. Doody. 2015. Implementing agricultural phosphorus science and management to combat eutrophication. Ambio 44(Suppl. 2):S297-S310.

Logan, T.J., and J.R. Adams. 1980. The effects of reduced tillage on phosphate transport from agricultural land. Lake Erie Wastewater Management Study. Buffalo, NY: US Army Corps of Engineers.

Maccoux, M.J.,A. Dove, S.M. Backus, and D.M. Dolan. 2016. Total and soluble reactive phosphorus loadings to Lake Erie: A detailed accounting by year, basin, country, and tributary. Journal of Great Lakes Research 42(6):11511165, http://dx.doi.org/10.1016/j.jglr.2016.08.005.

McConnell, D.A., C.P. Ferris, D.G. Doody, C.T. Elliot, and D.I. Mathews. 2013. Phosphorus losses from low-emission slurry spreading techniques. Journal of Environmental Quality 42(1):446-454.

Mehlich, A. 1978. New extractant for soil test evaluation of phosphorus, potassium, magnesium, calcium, sodium, manganese and zinc. Communications in Soil Science and Plant Analysis 9(6):477-492.

Mehlich, A. 1984. Mehlich 3 soil test extractant: A modification of Mehlich 2 extractant. Communications in Soil Science and Plant Analysis 15(12):1409-1416.

Nelson, W.L. 1967. Nitrogen, Phosphorus, and PotassiumNeeds and Balance for High Yields. In ASA Special Publication Number 9. Maximum Crop Yields-The Challenge, eds. D.A. Rohweder and S.E. Younts, 57-67. Madison,WI: American Society of Agronomy.

Ohio Legislature. 2015.Addresses agricultural regulations and application of fertilizer. https://www.legislature.ohio. gov/legislation/legislation-summary?id=GA131-SB-1.

Pierzynski, G.M. 1991. The chemistry and minerology of phosphorus in excessively fertilized soils. Critical Reviews in Environmental Control 21:265-295.

Pierzynski, G.M., R.W. McDowell, and J.T. Sims. 2005. Chemistry, cycling, and potential movement of inorganic phosphorus in soils. In Phosphorus: Agriculture and the Environment, Agronomy Monograph no. 46, ed. D.T. Westerman, 53-86, Madison, WI: American Society of Agronomy.

Reimer, A.P., D.K. Weinkauf, and L.S. Prokopy. 2012. The influence of perceptions of practice characteristics: An examination of agricultural best management practice adoption in two Indiana watersheds. Journal of Rural Studies 28:118-128.

Richards, R.P., D.B. Baker, and J.P. Crumine. 2009. Improved water quality in Ohio tributaries to Lake Erie: A consequence of conservation practices. Journal of Soil and Water Conservation 64(3):200-211, doi:10.2489/ jswc.64.3.200.

Scavia, D., M. Kalcic, R.L. Muenich, N. Aloysius, C. Boles, R. Confesor, J. DePinto, M. Gildow, J. Martin, J. Read, T. Redder, S. Sowa, Y. Wang, and H. Yen. 2016. Informing Lake Erie agriculture nutrient management via scenario 
evaluation. http://graham.umich.edu/water/project/ erie-western-basin.

Sharpley, A.N. 1981. The contribution of phosphorus leached from crop canopy to losses in surface runoff. Journal of Environmental Quality 10:160-165.

Sharpley, A.N., S.J. Smith, O.R. Jones, W.A. Berg, and G.A. Coleman. 1992. The transport of bioavailable phosphorus in agricultural runoff. Journal of Environmental Quality 21:30-35.

Smith, D.R., W. Francesconi, S.J. Livingston, and C. Huang. 2015. Phosphorus losses from monitored fields with conservation practices in the Lake Erie Basin, USA. Ambio 44(Suppl. 2):S316-S331.

Smith, D.R., R.D. Harmel, M. Williams, R. Haney, and K.W. King. 2016. Managing acute phosphorus loss with fertilizer source and placement: Proof of concept. Agricultural and Environmental Letters 1:150015, doi:10.2134/ael2015.12.0015

Smith, D.R., and P.A. Moore Jr. 2005. Soil extractable phosphorus changes with time after application of fertilizer: II. Manure from swine fed modified diets. Soil Science 170(8):640-651.

Smith, D.R., P.A. Moore Jr., and D.M. Miles. 2005. Soil extractable phosphorus changes with time after application of fertilizer: I. Litter from poultry fed modified diets. Soil Science 170(7):530-542.

Smith, D.R., P.R. Owens, A.B. Leytem, and E.A. Warnemuende. 2007. Nutrient losses from manure and fertilizer applications as impacted by time to first runoff event. Environmental Pollution 147:131-137.

Sommers, L.E., and A.L. Sutton. 1980. Use of waste materials as sources of phosphorus. In The Role of Phosphorus in Agriculture, eds. F.E. Khasawneh, E.C. Sample, and E.J. Kamprath, 515-544. Madison, WI: American Society of Agronomy.

Stumpf, R.P., L.T. Johnson, T.T. Wynne, and D.B. Baker. 2016. Forecasting annual cyanobacterial bloom biomass to inform management decisions in Lake Erie. Journal of Great Lakes Research 42(6):1174-1183, doi:http:// dx.doi.org/10.1016/j.jglr.2016.08.006.

Stumpf, R.P., T.T. Wynne, D.B. Baker, and G.L. Fahnenstiel 2012. Interannual variability of cyanobacterial blooms in Lake Erie. PLoS One 7(8):e42444, doi:http://dx/ doi.org/10.1371/journalpone.0042444.

Thomas, G.W., and J. Hanway. 1968. Determining fertilizer needs. In Changing Patterns in Fertilizer Use, eds. L.B. Nelson, M.H. McVickar, R.D. Munson, L.F. Seatz, S.L. Tisdale, and W.C. White, 119-140. Madison, WI: American Society of Agronomy.

USDA ERS (Economic Research Service). 2016. Fertilizer Use and Price. http://www.ers.usda.gov/dataproducts/fertilizer-use-and-price.aspx.

USDA NASS (National Agricultural Statistics Service). 2012. Ohio Agricultural Census. http://www. agcensus.usda.gov/Publications/2012/Full_Report/ Volume_1,_Chapter_1_State_Level/Ohio/.
USDA NRCS (Natural Resources Conservation Service) 2016. Effects of conservation practice adoption on cultivated cropland acres in Western Lake Erie Basin, 2003-06 and 2012. https://www.nrcs.usda.gov/ Internet/FSE_DOCUMENTS/nrcseprd889806.pdf.

Van Schilfgaarde, J., G.J. Kriz, N. Bouwes, J. Bucheim, J.M. Davidson, E.A. Hiler, A.G. Hornsby, H.P. Johnson, A. Miller, R.W. Skaggs, J.H. Snyder, P.M. Tidd, G.W. Thomas, and M.T. van Genuchten. 1981. Water-A basic resource. In Soil and Water Resources: Research Priorities for the Nation, eds. W.E. Larson, L.M. Walsh, B.A. Stewart, and D.H. Boelter, 1-19, Madison, WI: Soil Science Society of America.

Vezie, C., J. Rapala, J. Vaitomaa, J. Seitsonen, and K. Sivonen. 2002. Effect of nitrogen and phosphorus on growth of toxic and nontoxic Microcystis strains and on intracellular microcystin concentrations. Microbial Ecology 43(4):443-454.

Vitosh, M.L., J.W. Johnson, and D.B. Mengel. 1995. TriState Fertilizer Recommendations for Corn, Soybeans, Wheat and Alfalfa. East Lansing, MI: Michigan State University Extension. https://www.extension.purdue. edu/extmedia/AY/AY-9-32.pdf

Wadleigh, C.H., and R.S. Dyal. 1970. Soils and Pollution. In Agronomy and Health, ed. R.W. Blaser, 9-19. Madison, WI: American Society of Agronomy.

Watson, M., and R. Mullen. 2007. Understanding soil tests for plant-available phosphorus. The Ohio State University Extension Fact Sheet. https://agcrops.osu.edu/sites/ agcrops/files/imce/fertility/Soil_Tests_Plant_Avail.pdf.

Webb, J.R., and J.T. Pesek. 1958. An evaluation of phosphorus fertilizers varying in water solubility: I. Hill applications for corn. Soil Science Society of America Journal 22:533-538

Webb, J.R., and J.T. Pesek. 1959. An evaluation of phosphorus fertilizers varying in water solubility: II. Broadcast applications for corn. Soil Science Society of America Journal 23:381-384

Williams, M.R., G.W. Feyereisen, D.B. Beegle, and R.D. Shannon. 2011. Manure application under winter conditions: Nutrient runoff and leaching losses. Transactions of the American Society of Agricultural and Biological Engineers 54(3):891-899.

Williams, M.R., G.W. Feyereisen, D.B. Beegle, and R.D. Shannon. 2012. Soil temperature regulates phosphorus loss from lysimeters following fall and winter manure application. Transactions of the American Society of Agricultural and Biological Engineers 55(3):871-880.

Williams, M.R., K.W. King, W. Ford, A.R. Buda, and C.D. Kennedy. 2016. Effect of tillage on macropore flow and phosphorus transport to tile drains. Water Resources Research 52, doi:10.1002/2015WR017650. Wilson, R.S., G. Howard, and E.A. Burnett. 2014. Improving nutrient management practices in agriculture: The role of risk-based beliefs in understanding farmer's attitudes toward taking additional action. Water Resources Research 50:6735-6746.
Wines, M. 2014. Behind Toledo's water crisis, a long-troubled Lake Erie. The New York Times. August 4, 2014. http:// www.nytimes.com/2014/08/05/us/lifting-ban-toledosays-its-water-is-safe-to-drink-again.html.

Withers, P.J.A., D.M. Nash, and C.A.M. Laboski. 2005 Environmental management of phosphorus fertilizers. In Phosphorus: Agriculture and the Environment. Agronomy Monograph No. 46. Madison, WI: American Society of Agronomy, Crop Science Society of America, Soil Science Society of America.

WHO (World Health Organization). 2003. Cyanobacterial toxins: Microcystin-LR in drinking water. Geneva, $\mathrm{CH}$ : World Health Organization. http://www. who.int/water_sanitation_health/dwq/chemicals/ cyanobactoxins.pdf?ua $=1$.

Young, R.D., and C.H. Davis. 1980. Phosphate fertilizers and process technology. In The Role of Phosphorus in Agriculture, eds. F.E. Khasawneh, E.C. Sample, and E.J. Kamprath, 195-226. Madison, WI: American Society of Agronomy. 